\title{
MANAGEMENT OF RISKS OF WATER SUPPLY \\ AND WASTEWATER ENTERPRISES, AS PART OF THE STATE POLICY
}

\section{УПРАВЛІННЯ РИЗИКАМИ ПІДПРИЕМСТВ \\ ВОДОПОСТАЧАННЯ І ВОДОВІДВЕДЕННЯ \\ ЯК ЧАСТИНА ДЕРЖАВНОЇ ПОЛІТИКИ}

\section{Krylova Iryna ${ }^{1}$}

DOI: https://doi.org/10.30525/978-9934-571-78-7_39

Abstract. Water supply and wastewater security is part of the state policy of many countries and means reliable water supply of acceptable quantity and quality for health, livelihoods and production in combination with acceptable levels of risk. In addition, water supply and wastewater security provides for the protection of the environment and the efficient management of water resources. In Ukraine, water security is connected only with the quality of drinking water and the absence of danger of harmful effects on a person. In the article the author analyzes the principles of domestic state policy in the field of water supply and wastewater, provides an author's definition of the state policy in the field of water supply and wastewater and suggestions for its improvement. The article stipulates that water supply and wastewater security involves risk assessment at all stages of water supply from water intake to the delivery of services to the consumer with the further implementation and monitoring of risk control measures with an emphasis on priority risks. The risk inherently is not only the probability of an accident occurrence, but also the probability of a negative outcome. Risk in economic activity is a potential, numerically measurable possibility of occurrence of adverse situations or unsuccessful result of industrial-economic or other activity and related consequences in the form of losses, losses connected with uncertainty. Water supply and wastewater companies can face a number of risks that can negatively influence their activities. These include, in particular, environmental, political, legal, social, production risks, and

\footnotetext{
${ }^{1}$ Candidate of Legal Sciences, Doctoral Student,

National Academy for Public Administration under the President of Ukraine, Ukraine

(C) Krylova Iryna
} 
so on. Prevention of risks in the field of water supply and sewage involves the implementation of a complex of organizational and technical measures that are used to eliminate / minimize losses. Modular risk management for domestic water supply and wastewater companies is proposed. The matrix of determination of the level of risks that can arise in the system of water supply and wastewater is offered. An example of threats that can lead to violations in water supply and an assessment of threats (probability, consequences and risk level) are given. In the article, the author makes conclusions about the necessity of introducing a risk management system in the field of water supply and wastewater. In order to introduce water supply and wastewater systems at the water supply and wastewater enterprises, the state should provide among the principles of state policy safe water supply and wastewater and introduce a system of risk management related to the mentioned threats. At the same time, the risk management system related to the threats to safe water supply and wastewater should include identifying, analyzing and determining the degree of risk associated with threats, identification of the likely consequences, causes of their occurrence and scenarios of development, monitoring system and application of prevention and / or minimize the negative effects.

\section{1. Вступ}

Питна вода - найцінніший ресурс в будь-якому суспільстві, незалежно від соціально-економічних або екологічних умов його буття. Вода необхідна для всіх форм життя на нашій планеті. Ресурси питної води здатні як прискорити, так і обмежити соціальний розвиток і технічний прогрес; можуть бути причиною як благополуччя, так і бідності, привести як до співпраці, так і до конфліктів. Для забезпечення безпечного водопостачання необхідно захищати вразливі системи водних ресурсів, пом'якшувати наслідки стихійних лих, таких як повені та посухи, оберігати доступ до водних ресурсів та системи водопостачання, а також забезпечувати комплексне і справедливе управління водними ресурсами [15]. Управління водними ресурсами пов'язано із комплексом факторів, таких як державна політика, фінансування, розподіл ресурсів, екосистема, тощо, і має включати в себе забезпечення безпеки інфраструктури водопостачання та водовідведення (безпечне водопостачання).

У світовій практиці, безпечне водопостачання було визначено як «надійне забезпечення прийнятної кількості та якості води для здо- 


\section{Chapter «State administration»}

ров'я, засобів до існування та виробництва у поєднанні з прийнятним рівнем ризиків, пов'язаних з водою» [4; 7]. При цьому, оцінка ризиків на всіх етапах водопостачання від водозабору до передачі послуги споживачеві з подальшою реалізацією та моніторингом контрольних заходів з управління ризиками 3 акцентом на пріоритетні ризики, $\epsilon$ складовою процесу безпечного водопостачання [14]. Таким чином управління ризиками у сфері водопостачання та водовідведення $\epsilon$ певним процесом прийняття управлінських рішень та реалізації заходів із забезпечення мінімізації можливих ризиків.

На території України площею 603628 км² розміщена інфраструктура централізованого водопостачання та водовідведення, яка сьогодні обслуговує 99,3\% населення міст (95,06\% - водовідведення); 89,1\% населення селищ міського типу (61,3\% водовідведення); біля 30\% населення сіл (2,5\% водовідведення). Сумарна протяжність водопровідних мереж (без урахування Донецької області) у 2017 році становила - 104,154 тис. км [34, с. 37, 43, 47]. Основна відповідальність за управління власністю, експлуатацію та збереження інфраструктури лежить, в основному на органах місцевого самоврядування (комунальна власність), і в одиничних випадках на приватних компаніях, які управляють об'єктами цієї інфраструктури за договорами. Пошкодження або знищення інфраструктури водопостачання та водовідведення внаслідок зовнішніх чи внутрішніх чинників (терористичний напад, стихійне лихо, помилка персоналу тощо) може призвести до порушення процесу надання життєво важливих послуг у країні, що загрожує здоров'ю населення та навколишньому середовищу, та, в найгіршому випадку, призведе до втрат людського життя. Більше того системи водопостачання та водовідведення пов'язані з іншими інфраструктурними системами, наприклад, з енергетичною, транспортною, хімічною промисловістю, яка постачає хімікати для очищення питної води, що робить проблему безпеки більш масштабною. Тому, функціонування сфери водопостачання і водовідведення вимагає ефективного управління з урахуванням різних ризиків: економічних, політичних, правових, техногенних, екологічних тощо. Особливо актуальним це питання $\epsilon$ в сучасний період проведення антитерористичної операції в країні і підвищеного рівня небезпеки.

Підприємства водопостачання та водовідведення мають затверджені плани ліквідації аварійних ситуацій, ці документи є докумен- 
тами з обмеженим доступом. Разом з тим, слід зазначити, що сьогодні не існує державних або галузевих стандартів у сфері водопостачання та водовідведення, які регулюють управління ризиками, оцінку ризиків, попередження ризиків, реагування на інциденти безпеки та відновлення у цій сфері. У зв'язку з цим актуальним є дослідження проблеми оцінки і управління ризиками на підприємствах сфери водопостачання та водовідведення, саме як частини державної політики щодо забезпечення безпечного водопостачання та водовідведення.

\section{2. Державна політика у сфері водопостачання та водовідведення}

Одне із суспільно важливих завдань держави у сфері водопостачання та водовідведення - це забезпечення громадян якісними та доступними послугами водопостачання і водовідведення. Під час вирішення цього завдання держава має забезпечити також задоволення інтересів основних суб'єктів економіки з мінімальними негативними наслідками для кожного з них, адже успішне функціонування водогосподарських комплексів залежить від співпраці держави, виробників та споживачів послуг. При цьому держава, з одного боку, повинна створити відповідні безпечні умови для ефективного розвитку виробників - суб'єктів господарювання у сфері водопостачання та водовідведення, а з іншого - контролювати їх роботу на відповідність стандартам щодо таких показників, як якість та безпечність послуг, а також на справедливість установлених тарифів з урахуванням реальних доходів споживачів та фактичного рівня виробничих витрат на виробництво. Зазначені питання є питаннями державної політики країни у сфері водопостачання та водовідведення.

Державна політика (англ. Public Policy, State Policy) є складним та багатогранним явищем і тлумачиться науковцями: - як дії системи органів державної влади згідно з визначеними цілями, напрямами, принципами для розв'язування сукупності взаємопов'язаних проблем у певній сфері суспільної діяльності. Це пропонований курс діяльності уряду для задоволення потреб чи використання можливостей, сформульований із зазначенням очікуваних результатів та їх впливу на наявний стан справ і конкретне розв'язання проблем. Ефективність державної політики, як і державного управління, полягає в поліпшенні якості життя громадян, у гарантуванні соціальної стабільності, забезпеченні національної безпеки країни [27, с. 144-145]; - як сукупність 


\section{Chapter «State administration»}

ціннісних цілей, державно-управлінських заходів, рішень і дій, порядок реалізації державно-політичних рішень (поставлених державною владою цілей) і системи державного управління розвитком країни $[19$, c. 8$]$; - як вибір державними інституціями між діяльністю та бездіяльністю щодо вирішення суспільних проблем [48, с. 7]; \}- як оптимальний синтез об'єктивних тенденцій суспільного розвитку і суб'єктивних суджень людей про власні інтереси в суспільстві [16]; - як діяльність органів державної влади з управління та керівництва суспільством на основі єдиних цілей, принципів і методів, яка передбачає розробку, законодавче закріплення та впровадження державних цільових програм у різних сферах суспільного життя з метою розв'язання нагальних проблем чи задоволення потреб суспільства [35]; - як цілеспрямована діяльність органів державної влади, що формується та здійснюється державними інститутами та спрямована на збалансування інтересів різних суспільних груп у державі [17, с. 8].

Аналіз наведених визначень поняття «державної політики» у вітчизняній науковій літературі свідчить про актуальність цього питання та про наявність різних варіантів його розуміння. 3 усіх варіантів коротко можна виділити спільні критерії державної політики, як то діяльність органів державної влади та вирішення суспільних проблем. Звідси випливає зміст або сутність державної політики, що становить сукупність цілей, завдань, пріоритетів розвитку, програм, які розробляють і реалізують органи державної влади із залученням інститутів громадянського суспільства [19, с. 51]. Найбільш важливими характеристиками державної політики визначені: реагування на зміни, що відбуваються в суспільстві та державі; комплексний підхід і розгляд кожної проблеми у взаємозв'язку з іншими проблемами; ефективність та раціональність; довіра в населення [19, с. 27-28].

Визначальним для державної політики є результат ii реалізації, тобто кількісний вимір ії цілей. У процесі формування державної політики в контексті цілепокладання будь-яка, навіть найскладніша й абстрактна проблема, може бути зведена до певного переліку складових, що мають кількісне вираження. Відомо, що якість управлінської діяльності держави залежить від кількісного виміру показників діяльності іiі органів влади, насамперед у частині вираження цілей. Кількісні критерії доцільно застосовувати ще й для зіставлення різних групових інтересів, співвіднесення фінансових витрат на ті чи інші цілі 
$[19$, с. 8]. Основний процес, що концептуалізує формування державної політики - це раціональна аргументація. Раціональність як базова процесуальна характеристика держави, домінуючий спосіб забезпечення ії життєдіяльності також утверджується й шляхом формування державної політики і полягає в практиці узгодження цілей різних груп інтересів через змагальність аргументів, спроби переконання опонентів у справедливості своїх позицій та оцінок. І головний, хоча й не єдиний критерій у цьому процесі, - вартість ресурсів, що виділятимуться для досягнення поставлених цілей [19, с. 8].

Становлення державної політики відбувається під впливом внутрішніх та зовнішніх факторів, які можна систематизувати таким чином. До зовнішніх факторів належать: політичні (групи інтересів, групи тиску на владу; лобістські організації; політичні партії; засоби масової інформації; громадська думка тощо); інституціональні (законодавчі, виконавчі, судові органи влади; органи місцевого самоврядування тощо); економічні (економічні програми, матеріальні та фінансові ресурси тощо); соціальні (соціальні цінності та норми; професійна етика та традиції тощо); технологічні (інноваційні технології; поширення товарів і послуг). До внутрішніх факторів відносять поведінку та діяльність органів державної влади, що безпосередньо беруть участь у процесі формування та реалізації державної політики.

Державна політика у сфері водопостачання та водовідведення формувалась в контексті житлово-комунальної галузі. Під час ринкових перетворень державна політика була направлена на формування державної системи регулювання цін і тарифів в житлово-комунальному господарстві і роздержавлення підприємств житлово-комунального господарства (в т.ч. водопровідно-каналізаційного господарства). Держава передала підприємства водопровідно-каналізаційного господарства до комунальної власності місцевих територіальних органів. Надмірна фрагментація підприємств водопровідно-каналізаційного господарства та відсутність досвіду на місцях у питанні регулювання суб' єктів природних монополій призвела не тільки до загального занепаду галузі, але й до великих економічних витрат для національної економіки. Формування державної політики у сфері відбувалось на основі аналізу проблеми та причин незадовільного стану водопровідно-каналізаційної галузі, пропозицій міністерств та інших центральних органів виконавчої влади, Ради міністрів Автономної Республіки 


\section{Chapter «State administration»}

Крим, обласних, Київської та Севастопольської міських державних адміністрацій, підприємств водопровідно-каналізаційного господарства, науково-дослідних і проектних інститутів для iіi реформування центрального органу з питань будівництва, архітектури та житлової політики (суб' єктів державної політики). І все це відбувалось в мирний час. В результаті двадцятирічного реформування водопровідно-каналізаційної галузі, прийняття ряду державних програм: розвитку водопровідно-каналізаційного господарства (постанова Кабінету Міністрів України від 17.11.1997 р. № 1269), «Питна вода України» (Закон України від 03.03.2005 р. № 2455-ІУ), держава визначила пріоритетною сферою для державної політики сферу питної води та питного водопостачання.

Метою державної політики в цій сфері - $є$ вирішення проблеми забезпечення гарантованих Конституцією України прав громадян на достатній життєвий рівень та екологічну безпеку шляхом забезпечення питною водою в необхідних обсягах та відповідно до встановлених нормативів. Оптимальним варіантом розв'язання проблеми $\epsilon$ реалізація державної політики щодо розвитку та реконструкції систем централізованого водопостачання та водовідведення; охорони джерел питного водопостачання; доведення якості питної води до вимог державних стандартів; нормативно-правового забезпечення у сфері питного водопостачання та водовідведення; розроблення та впровадження науково-дослідних і дослідно-конструкторських розробок із застосуванням новітніх матеріалів, технологій, обладнання та приладів [28].

Таким чином, державна політика легітимізувалась у профільному Законі України «Про питну воду, питне водопостачання та водовідведення». Державна політика у сфері питної води та питного водопостачання базується на принципах: державного управління і регулювання відносин; пріоритетності питного водопостачання перед іншими видами спеціального водокористування; гарантованого першочергового забезпечення питною водою населення для забезпечення питних, фізіологічних, санітарно-гігієнічних та побутових потреб; раціонального використання питної води; науково обгрунтованого нормування якості питної води, нормативів іiї споживання та формування тарифів на послуги централізованого водопостачання і водовідведення; наближення вимог національних стандартів на питну воду, питне водопостачання та водовідведення, технологій виробництва питної води, 
нормативів щодо очищення стічних вод, а також засобів вимірювання і методів оцінки до відповідних стандартів, нормативів, технологій, засобів і методів, прийнятих у $\mathrm{CC}$; запобіжного характеру заходів щодо охорони джерел і систем питного водопостачання; дотримання оптимального балансу використання поверхневих і підземних вод для питного водопостачання; обов'язковості державної експертизи i оцінки експлуатаційних запасів підземних вод для питного водопостачання; обов'язковості оцінки впливу на довкілля і державної санітарно-епідеміологічної експертизи проектів господарської, інвестиційної та іншої діяльності, яка може негативно вплинути на стан джерел і систем питного водопостачання; економічного стимулювання раціонального використання питної води споживачами; невідворотності відповідальності у разі порушення законодавства у сфері; відшкодування збитків, завданих внаслідок порушення законодавства у сфері; забезпечення вільного доступу до інформації про якість питної води, стан джерел та систем питного водопостачання та водовідведення, порядку формування нормативів питного водопостачання та тарифів на послуги централізованого водопостачання і водовідведення; додержання єдиних правил, норм і стандартів усіма суб'єктами відносин у сфері питної води, питного водопостачання та водовідведення; ліцензування господарської діяльності із централізованого водопостачання та водовідведення; заборони відключення об'єктів питного водопостачання та централізованого водовідведення від системи енерго-, газо-, теплопостачання як об'єктів життєзабезпечення і стратегічного значення [40].

Таким чином, державна політика у сфері водопостачання та водовідведення - це система принципів та напрямів держави, яка має базуватись на захисті інтересів суб'єктів відносин у сфері водопостачання та водовідведення, забезпечення безпечного водопостачання та водовідведення, державного регулювання, розвитку економіки країни, тощо. Проте, слід зазначити, що профільне законодавство у сфері водопостачання та водовідведення потребує нового підходу до безпечного водопостачання та водовідведення і врегулювання питання управління ризиками в цій сфері. При цьому, державна політика в частині управління ризиками у сфері водопостачання та водовідведення має включати в себе різні джерела небезпеки та різні ризики від природних та техногенних до військових конфліктів та загроз тероризму. 


\section{Chapter «State administration»}

\section{3. Ризики у діяльності підприсмств водопостачання та водовідведення}

У масовій свідомості поняття ризику пов'язується 3 небезпекою, загрозою, ненадійністю, невизначеністю, непевністю, випадковістю, збитком. У Словнику української мови «ризик» визначається як: 1) усвідомлена можливість небезпеки; 2) можливість збитків або невдачі в якійсь справі [46]. Термін «ризик» можна застосовувати, коли йдеться про подію, яка призводить до збитків: «Ризик - це небезпека втрат і можливість одержання збитків» (Л. Тепман) [49]. Інші зарубіжні вчені визначають поняття ризику таким чином: Дж. Сінкі: «Ризик - це невизначеність, пов'язана з будь-якою подією або іiі наслідками» [45]; Дж. Террі: «Ризик - нестабільність, невпевненість у майбутньому, точніше, рівень невизначеності» [12]. Вітчизняні дослідники Л. І. Донець, С.М. Клименко поняття «ризик» пов'язують з небезпекою в будь-якій сфері господарської діяльності та соціально-економічного життя [21; 29]. Під господарським (підприємницьким) ризиком прийнято розуміти ризик, що виникає при будь-яких видах діяльності, пов'язаних з виробництвом продукції, товарів, послуг, їх реалізацією, товарно-грошовими, і фінансовими операціями, комерцією, здійсненням соціально-економічних і науково-технічних проектів. Підприємницький ризик характеризується як небезпека потенційно можливої, ймовірної втрати ресурсів чи недоодержання доходів у порівнянні з варіантом, розрахованим на раціональне використання ресурсів у даному виді підприємницької діяльності [47].

У наукових працях представлено різноманітні класифікації ризиків, які відрізняються за різними ознаками: за масштабами та рівнем виникнення; за сферою походження; за ступенем об'єктивності та суб'єктивності рішень; за ступенем ризиконасиченості рішень; за типами обгрунтованості ризику; за часом прийняття ризикованих рішень; за чисельністю осіб, що приймають рішення; щодо ситуації; за ступенем системності; за приналежністю до країни господарюючого суб'єкта; за можливістю прогнозування; залежно від можливого результату ризикової події $[21 ; 29 ; 32]$.

В нашому дослідженні ми розглянемо види ризиків за сферою походження, які зазвичай поділяють на: соціально-політичні ризики, походження яких базується на можливості виникнення непередбачених ситуацій у випадку зміни здійснюваного державою політичного курсу, а також можливого введення в дію незапланованих раніше соціальних 


\section{Krylova Iryna}

програм або інших дій, що в основі свого походження мають соціальну сферу (наприклад, страйки, зміна психологічного настрою в колективі і т.д.); адміністративно-законодавчі ризики, які виникають у випадку реалізації незапланованих адміністративних обмежень господарської діяльності ринкових суб'єктів, а також змін у законодавстві (наприклад, збільшення податкових ставок, заборона на здійснення певних видів діяльності і т.д.); виробничі ризики, які пов'язані з виробництвом продукції (товарів, послуг), зі здійсненням будь-яких видів виробничої діяльності (наприклад, скорочення очікуваних обсягів виробництва, зростання витрат на виробництво продукції і т.д.); комерційні ризики, які виникають у процесі реалізації товарів і послуг, вироблюваних або закуплених підприємством (наприклад, зменшення обсягів реалізації, підвищення закупівельної ціни товарів і т. д.); фінансові ризики, які виникають у сфері відносин підприємства з банками й іншими фінансовими інститутами, а також пов'язані з невиконанням суб'єктом економічної діяльності своїх фінансових зобов'язань (наприклад, прострочення платежів, порушення термінів повернення кредитів $\mathrm{i}$ т.д.); природно-екологічні ризики, які виникають внаслідок залежності людини й у цілому суспільного виробництва від природно- кліматичних умов, а також зворотного зв'язку між суспільним виробництвом і навколишнім середовищем (наприклад, несприятливий вплив шкідливих виробництв на здоров'я людей і т.д.), тощо [21; 29; 32].

Специфіку ризиків у сфері водопостачання та водовідведення визначає специфіка діяльності підприємств у цій сфері. Зокрема, особливості правового статусу підприємств водопостачання та водовідведення визначені Водним кодексом України, Законами України «Про питну воду, питне водопостачання та водовідведення», «Про природні монополії», «Про ліцензування видів господарської діяльності», «Про охорону праці», «Про об’єкти підвищеної небезпеки» та ін., які зобов'язують підприємства вживати певних заходів, отримувати ліцензії та дозвільні документи, приймати внутрішні акти тощо. У своїй діяльності підприємства водопостачання та водовідведення можуть стикатися з різними ризиками, які негативно впливатимуть на їх діяльність, на здоров'я та безпеку їх персоналу, на навколишнє природне середовище, на здоров'я та безпеку населення, тощо. Узагальнений перелік видів можливих ризиків в діяльності підприємств водопостачання та водовідведення наведено у таблиці 1. 


\begin{tabular}{|c|c|}
\hline & $\begin{array}{c}\text { Види ризиків для підприсмств } \\
\text { рери водопостачання та водовідведення }\end{array}$ \\
\hline $\begin{array}{c}\text { Види } \\
\text { потенційних } \\
\text { ризиків } \\
\end{array}$ & Ймовірність наслідків \\
\hline Екологічні & $\begin{array}{l}\text { Ймовірність несприятливих для навколишнього середовища } \\
\text { наслідків будь-яких змін природних об’єктів і факторів. } \\
\text { Техногенний аспект екологічного ризику - ймовірність } \\
\text { виникнення техногенних аварій, що здатні завдати істотної } \\
\text { шкоди навколишньому середовищу або здоров'ю людей. } \\
\text { Ймовірність виникнення негативних змін у водному середовищі, } \\
\text { віддалених несприятливих наслідків цих змін, що виникають } \\
\text { внаслідок негативного впливу на довкілля природних } \\
\text { катаклізмів. Ймовірність збільшення кількості захворювань } \\
\text { людей при підвищенні концентрації забруднюючих речовин } \\
\text { у воді або порушенні інших характеристик води. Ймовірність } \\
\text { впливу сезонності на якість послуг з питного водопостачання } \\
\text { та водовідведення (сезонність впливає на рівень концентрації } \\
\text { забруднення. Коливання в різні періоди року можуть бути } \\
\text { різкими, що суттєво збільшує навантаження на підприємство } \\
\text { та може потягти за собою зниження якості питної води). } \\
\text { Ймовірність несанкціонованих скидів токсичних речовин } \\
\text { у систему водовідведення. Ймовірність витоків хімічних } \\
\text { (дезінфікуючих) речовин тощо. }\end{array}$ \\
\hline Політичні & $\begin{array}{l}\text { Ймовірність виникнення збитків та зниження розміру прибутку } \\
\text { внаслідок державної політики, прийняття органами влади } \\
\text { непопулярних адміністративних рішень, неефективної тарифної } \\
\text { політики тощо або відсутність державного регулювання } \\
\text { (відсутність необхідних нормативно-правових актів для } \\
\text { врегулювання певних питань), тощо. }\end{array}$ \\
\hline Правові & $\begin{array}{l}\text { Ймовірність прийняття нормативно-правових актів, що вплинуть } \\
\text { на фінансово-економічний стан підприємства (зовнішні правові } \\
\text { фактори). } \\
\text { Ймовірність відсутності технічної, дозвільної документації } \\
\text { (внутрішні правові фактори). } \\
\text { Ймовірність впливу судових рішень на діяльність підприємства. } \\
\text { Ймовірність порушення контрагентами умов договорів. } \\
\text { Ймовірність отримання адміністративних стягнень у зв'язку з } \\
\text { порушенням чинного законодавства. }\end{array}$ \\
\hline Економічні & $\begin{array}{l}\text { Ймовірність виникнення зовнішніх економічних факторів: } \\
\text { інфляція, дефляція, рівень доходу населення, рівень зайнятості, } \\
\text { нестабільність економічного стану, відсутність фінансування } \\
\text { галузі тощо. }\end{array}$ \\
\hline
\end{tabular}


Закінчення таблиці 1

\begin{tabular}{|c|c|}
\hline $\begin{array}{c}\text { Види } \\
\text { потенційних } \\
\text { ризиків }\end{array}$ & Ймовірність наслідків \\
\hline Економічні & $\begin{array}{l}\text { Ймовірність виникнення внутрішніх економічних факторів: } \\
\text { недосконалість тарифної політики, відсутність власних } \\
\text { коштів та інвестицій на оновлення основних фондів, низький } \\
\text { збір платежів за надані послуги, виникнення кредиторської } \\
\text { заборгованості перед ресурсозабезпечуючими організаціями } \\
\text { (енергетичними, підприємствами з виробництва дезінфікуючих } \\
\text { засобів тощо), тощо. }\end{array}$ \\
\hline Соціальні & $\begin{array}{l}\text { Особливість діяльності підприємств водопостачання та } \\
\text { водовідведення в тому, що вони виробляють соціально значущі } \\
\text { послуги, тому будь-яка зміна якості чи вартості послуг впливає } \\
\text { на споживача. Имовірність соціальних протестів, соціального } \\
\text { несприйняття тощо. }\end{array}$ \\
\hline Виробничі & $\begin{array}{l}\text { Виробничі або виробничо-технологічні ризики в діяльності } \\
\text { підприємства проявляються у вигляді незапланованих зупинок } \\
\text { технологічного процесу, зниженні показників якості послуг тощо. } \\
\text { Ймовірність збитків або додаткових витрат, пов’язаних } \\
\text { з незадовільним станом основних виробничих фондів, } \\
\text { трубопровідних мереж, що призводить до аварій, збоїв або } \\
\text { зупинки виробничих процесів. }\end{array}$ \\
\hline Терористичні & $\begin{array}{l}\text { Терористичні ризики в діяльності підприємств виникли з } \\
\text { моменту оголошення АТО в країні і пов’язані із можливим } \\
\text { зовнішнім військовим втручанням в роботу підприємств чи } \\
\text { інфраструктури. } \\
\text { Ймовірність збитків для підприємства, ймовірність небезпеки } \\
\text { для здоров'я персоналу та населення, ймовірність екологічної } \\
\text { катастрофи тощо. }\end{array}$ \\
\hline
\end{tabular}

Зазначені види ризику є умовними і не остаточними, оскільки залежать від багатьох особливостей, тісно пов'язані між собою та можуть взаємно перетинатися, підсилювати дію або бути складовими один одного. Для детального аналізу ситуації кожний вид ризику має бути проаналізований, змодельований, розкладений на елементи, що дасть можливість певною мірою зменшити невизначеність ситуації.

Разом $з$ тим, створення ризикової ситуації обумовлено такими об'єктивними факторами: випадковий характер подій, що визначають, який $з$ можливих насідків реалізується на практиці; відомі ймовірності наслідків і очікувані результати; непередбачені зміни у внутрішніх і зовнішніх умовах діяльності; наявність альтернативних рішень; ймо- 


\section{Chapter «State administration»}

вірність виникнення збитків, тощо [50]. Зазначені фактори є зовнішньою характеристикою виникнення ризикової ситуації. Але управління цією ситуацією здійснюється самим підприємством, підприємство самостійно робить вибір з декількох альтернатив, має в розпорядженні об’єктивні ймовірності одержання передбачуваного результату.

\section{4. Регламентація управління ризиками: національний та міжнародний досвід}

Аналіз ризиків є частиною системного підходу до прийняття важливих рішень як на державному так і на місцевому рівнях, запровадження практичних заходів для попередження або зменшення небезпеки від аварій на виробництві для життя людини, захворювань чи травм, збитків для підприємства та навколишнього природного середовища.

Міжнародні політики та стандарти управління ризиками. Стандарт ISO/IEC 31000 «Ризик-менеджмент. Принципи та керівництва із застосування» (англ. Risk Management - Principles and Guidelines on Implementation) був розроблений міжнародною організацією зі стандартизації (англ. International Organization for Standardization). Основні стадії управління ризиками за цим стандартом, «Ідентифікація ризику», «Аналіз ризику», «Оцінювання ризику», розглядаються як складові стадії «Оцінка ризику», тому що сам процес управління ризиком не існує сам по собі, а має стати складовим елементом управління на підприємстві, впроваджуватися на всіх корпоративних рівнях під діючі бізнес-процеси [10]. COSO ERM «Управління ризиками організацій. Інтегрована модель», розроблений Комітетом спонсорських організацій комісії Тредвея (англ. Committee of Sponsoring Organizations of the Treadway Commission). Цей документ описує концептуальні основи управління ризиками підприємств, в якому міститься детальна інформація та рекомендації стосовно створення корпоративної системи ризик-менеджменту в рамках підприємства [3]. FERMA «Управління ризиками Федерації європейських асоціацій ризик-менеджменту» (англ. The Federation of European Risk Management), який $\epsilon$ спільною розробкою Інституту ризик-менеджменту (англ. Institute of Risk Management - IRM) та Асоціації страховиків та ризик-менеджерів в промисловості та торгівлі (англ. Association of Insurance and Risk Managers in Industry and Commerce - AIRMIC). На відміну від стандарту COSO, стандарт FERMA в частині термінологічних описів 
дотримується підходу, прийнятого в документах Міжнародної організації зі стандартизації (ISO/IEC 73:2002. Менеджмент ризику, терміни та визначення). Зокрема, ризик визначається стандартом як комбінація ймовірності події та ії̈ наслідків, що обмежує можливості аналізу ризиків. Однак, у стандарті FERMA ризик-менеджмент розглядається як невід'ємна центральна складова управління підприємством та (або) проектами [6].

Основні міжнародні стандарти 3 ризик менеджменту наведено в таблиці 2.

Зазначені стандарти забезпечують основу для прийняття рішення про найбільш доцільний підхід до управління ризиками, також можуть використовуватися для прийняття рішення щодо конкретних ризиків або вибору між різними варіантами. Вибір стандарту управління ризиками залежить від рівня зрілості процесів управління ризиками. Застосування певної моделі управління ризиком, встановленої стандартом, має забезпечити ефективність ризик-менеджменту, його імплементацію та інтеграцію в загальну систему управління підприємства, що дає змогу ефективно використовувати інформацію про ризик та управління ризиком в рамках підприємства.

Крім того, європейське законодавство у сфері цивільного захисту та діяльності, пов'язаної з об'єктами підвищеної небезпеки складається 3: Директиви 2012/18/ЄС Свропейського парламенту і ради про контроль великих аварій, пов'язаних з небезпечними речовинами (CEBE3О III) та Директиви 2007/60/СС про оцінку та управління ризиками повеней. Основна мета Директиви CEBEЗО III має два напрями. Насамперед вона спрямована на запобігання великим аваріям 3 утворенням небезпечних речовин. По-друге, Директива спрямована на мінімізацію наслідків аварій для людини (безпека й здоров'я) і для довкілля (екологічний аспект). Своїми положеннями Директива вимагає від промисловості: детального повідомлення про види та кількість усіх небезпечних речовин, що перебувають або використовуються на об'єкті; наявності плану дій на випадок аварії й демонстрації його ефективності; наявності системи керування безпекою для перевірки й контролю ефективності процедур з експлуатації та безпеки; здійснення оцінки ступеня ризику при визначенні потенційних проблем, пов'язаних зі зберіганням і переробкою у гірничовидобувній промисловості; розроблення політики щодо запобігання великим аваріям [20]. 


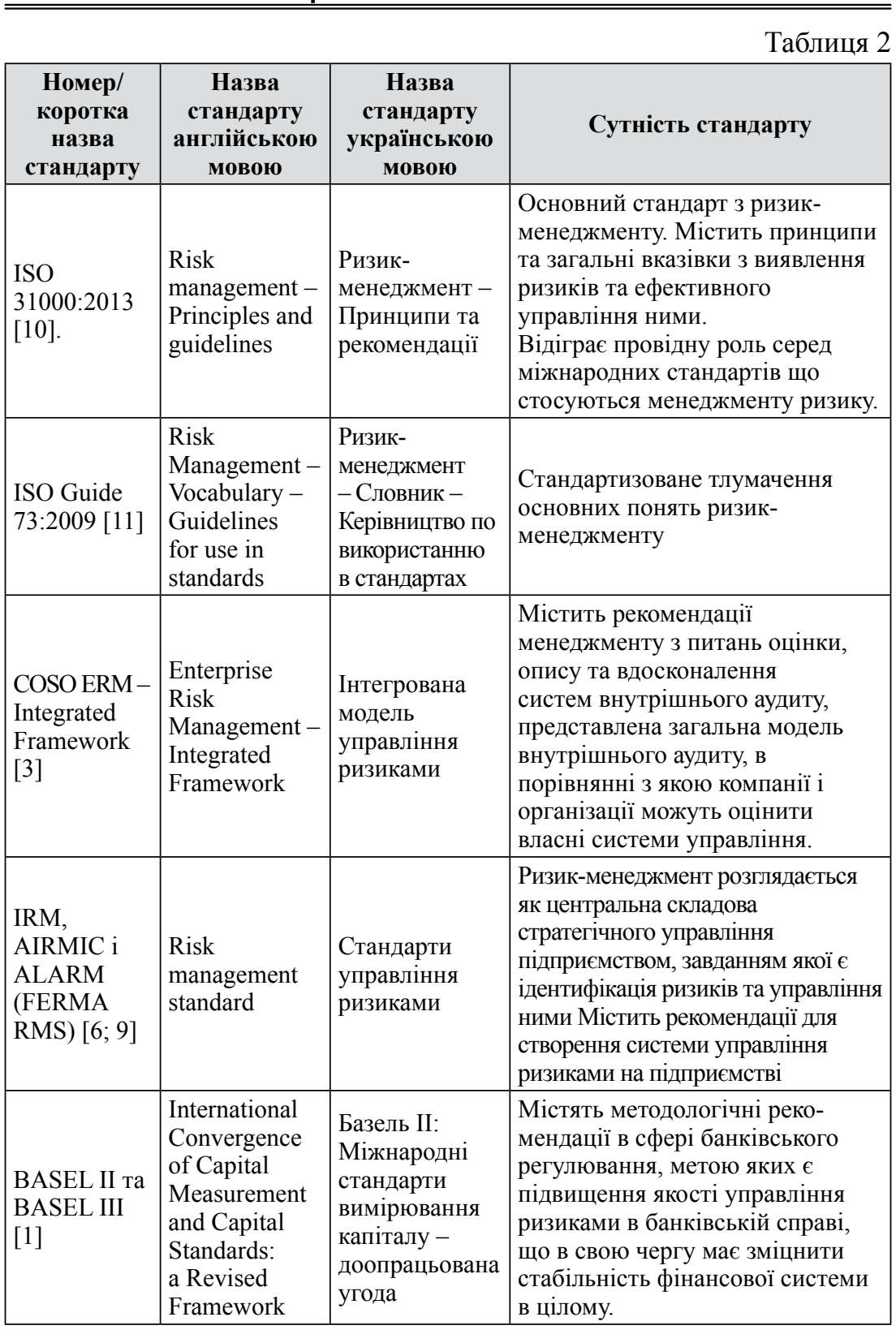


Аналізуючи ситуацію в Україні з базою даних і доступними методиками розрахунків ризиків, слід відзначити їх практично повну відсутність і орієнтацію нормативних актів на особливо небезпечні об'єкти, забезпечення санітарного та епідемічного благополуччя населення. В Україні прийнято відповідні аналоги стандартів 2009 року: ДСТУ ISO Guide 73:2013 «Керування ризиком. Словник термінів»; ДСТУ ISO 31000:2014 «Менеджмент ризиків. Принципи та керівні вказівки»; ДСТУ ISO/IEC 31010:2013 «Керування ризиком. Методи загального оцінювання ризику» [22; 23; 24]. Ці стандарти (ДСТУ) не є обов'язковими стандартами для впровадження підприємствами, але можуть бути корисними для підприємств у разі добровільної сертифікації процесу управління. Оскільки сфера управління ризиками згідно із Законом України «Про технічні регламенти та оцінку відповідності» належить до законодавчо нерегульованої сфери, в ній здійснюється добровільна оцінка відповідності (тобто на добровільних засадах, в будь-яких формах, включаючи випробування, декларування відповідності, сертифікацію та інспектування, та на відповідність будь-яким заявленим вимогам). 3 іншого боку, в країні триває імплементація європейських директив, в тому числі, СЕВЕЗО III.

Як було зазначено раніше в національному законодавстві питання управління ризиками орієнтовано в основному на особливо небезпечні об'єкти (до яких відносяться об'єкти підприємств водопостачання та водовідведення), а також на забезпечення санітарного та епідемічного благополуччя населення. Основним нормативно-правовим актом, що визначає правові, економічні, соціальні та організаційні основи діяльності, пов'язаної з об' єктами підвищеної небезпеки, і спрямований на захист життя і здоров'я людей та довкілля від шкідливого впливу аварій на цих об'єктах шляхом запобігання їх виникненню, обмеження (локалізації) розвитку і ліквідації наслідків, є Закон України «Про об'єкти підвищеної небезпеки» [39]. Зазначеним Законом визначено поняття ризику, як ступеню імовірності певної негативної події, яка може відбутися в певний час або за певних обставин на території об'єкта підвищеної небезпеки i/або за його межами, та управління ризиком, як процесу прийняття рішень і здійснення заходів, спрямованих на забезпечення мінімально можливого ризику.

Суспільні відносини, які виникають у сфері забезпечення санітарного та епідемічного благополуччя регулюються Законом України 


\section{Chapter «State administration»}

«Про забезпечення санітарного та епідемічного благополуччя населення» [36]. Згідно із цим Законом, ризиком є можливість виникнення та вірогідні масштаби наслідків від негативного впливу об'єктів санітарних заходів протягом певного періоду часу. Аналіз ризику $є$ процесом, що складається з трьох взаємозв'язаних компонентів: оцінка ризику, управління ризиком та повідомлення про ризик. Управління ризиком - процес вибору альтернативних рішень на підставі результатів оцінки ризику та, у разі необхідності, вибору і впровадження відповідних засобів управління (контролю), включаючи регуляторні заходи. Зазначені Закони зобов'язують підприємства та власників підприємств забезпечувати їх необхідними для розробки та здійснення санітарних та протиепідемічних (профілактичних) заходів санітарними нормами, а також забезпечувати експлуатацію об'єктів підвищеної небезпеки 3 додержанням мінімально можливого ризику.

Методика визначення ризиків та їх прийнятних рівнів для декларування безпеки об'єктів підвищеної небезпеки затверджена наказом Міністерства праці та соціальної політики України від 04.12.2002 p. № 637 «Про затвердження Методики визначення ризиків та їх прийнятних рівнів для декларування безпеки об'єктів підвищеної небезпеки» (Методика № 637). Зазначена Методика визначає порядок проведення аналізу небезпеки та оцінки ризику об'єктів підвищеної небезпеки, установлює методичні принципи, терміни і поняття аналізу ризику, визначає критерії прийнятних ризиків та їх рівні. Методика №637 призначена: для розробки декларації безпеки об'єктів підвищеної небезпеки; для прийняття рішень щодо розташування та експлуатації об'єктів підвищеної небезпеки; для розробки заходів щодо запобігання аварій та підготовки до реагування на них; для визначення обсягу відповідальності та страхових тарифів при страхуванні цивільної відповідальності суб'єктів господарської діяльності за шкоду, що може бути заподіяна аваріями на об'єктах підвищеної небезпеки відповідно до вимог Законів України «Про об'єкти підвищеної небезпеки» та «Про страхування». Методика № 637 вимагає від підприємства прийняття внутрішніх нормативно-правових актів та їх виконання, таких як декларація безпеки об'єктів підвищеної небезпеки; заходів щодо запобігання аварій та підготовки до реагування на них; відомчих або галузевих керівних документів з проведення аналізу ризику об'єктів підвищеної небезпеки відповідно до їх специфіки тощо [37]. 
Розрахунок розміру можливих збитків від наслідків надзвичайних ситуацій техногенного і природного характеру, завданих здоров'ю людей та об'єктам національної економіки, здійснено відповідно до Методики оцінки збитків від наслідків надзвичайних ситуацій техногенного і природного характеру, затвердженої постановою Кабінету Міністрів України від 15.02.2002 р. № 175 [38].

Таким чином, питання управління ризиками в сфері водопостачання та водовідведення несистематизовано в окремому нормативно-правовому акті, а регулюється різними законами в сфері небезпечних об'єктів та забезпечення санітарного та епідемічного благополуччя населення. На рівні державної політики в сфері водопостачання та водовідведення питання управління ризиками взагалі не визначено. Сдиним документом, що визначає ризики, їх оцінку та аналіз $є$ Методика визначення ризиків та їх прийнятних рівнів для декларування безпеки об'єктів підвищеної небезпеки затверджена наказом Міністерства праці та соціальної політики України від 04.12.2002 р. № 637, яка не враховує всі небезпеки сьогодення. Серед реформ та законодавчих змін, які зараз впроваджуються в Україні, важливою частиною $є$ виконання екологічної складової Угоди про асоціацію з СС. І хоча адаптація національного законодавства до законодавства ЄС триває більше 10 років, актуалізації це питання набуло з 1 вересня 2017 року, коли стартувала реалізація Угоди про асоціацію Україна-ЄС у повному обсязі. За останні роки прийнято ряд нормативно-правових актів, які є правовою підставою для розробки нормативних актів з питань управління ризиками виникнення надзвичайних ситуацій техногенного та природного характеру, в тому числі у сфері експлуатації об'єктів житлово-комунального господарства. Зокрема, розпорядженням Кабінету Міністрів України від 22.01.2014 р. № 37-р схвалено Концепцію управління ризиками виникнення надзвичайних ситуацій техногенного та природного характеру, метою якої $є$ запровадження сучасних методів управління ризиками для зменшення кількості та мінімізації соціально-економічних наслідків надзвичайних ситуацій, забезпечення досягнення гарантованого рівня безпеки громадянина і суспільства через затвердження планів управління ризиками в різних сферах господарської діяльності. Розпорядженням Кабінету Міністрів України від 06.12.2017 р. № 1009-р схвалено Концепцію створення державної системи захисту критичної інфраструктури, метою якої є визначення основних напрямів, механізмів і строків комплексного 


\section{Chapter «State administration»}

правового врегулювання питання захисту критичної інфраструктури та створення системи державного управління у сфері захисту критичної інфраструктури. Створення державної системи захисту критичної інфраструктури спрямоване на забезпечення стійкості критичної інфраструктури до загроз усіх видів, включаючи загрози природного і техногенного характеру, загрози, спричинені протиправними діями, та інші загрози. Розпорядженням Кабінету Міністрів України від 31.01.2018 р. № 43-р схвалено Концепцію розвитку та технічної модернізації системи централізованого оповіщення про загрозу виникнення або виникнення надзвичайних ситуацій, яка має вирішити проблему гарантованого i своєчасного оповіщення та інформування населення в разі виникнення надзвичайних ситуацій (існуюча система оповіщення створена в 70-80-х роках минулого століття за командно-сигнальним принципом в умовах глобального воєнного протистояння та орієнтована на доведення сигналів оповіщання лише в особливий період. На даний час система оповіщення не відповідає сучасним вимогам). Постановою Кабінету Міністрів України від 26.09.2018 р. № 779 «Деякі питання запобігання виникненню надзвичайних ситуацій природного та техногенного характеру» надано доручення центральним органам виконавчої влади, Раді міністрів Автономної Республіки Крим, обласним, Київській та Севастопольській міським, районним, районним у мм. Києві та Севастополі державним адміністраціям, військово-цивільним адміністраціям, органам місцевого самоврядування та об'єктам незалежно від форми власності, порушення функціонування яких може завдати шкоди життєво важливим національним інтересам та які є об'єктами підвищеної небезпеки, в частині уточнення планів реагування на надзвичайні ситуації і планів локалізації та ліквідації наслідків аварій, здійснення заходів щодо запобігання їх виникненню; готовності до здійснення оповіщення органів управління та сил цивільного захисту, населення про загрозу виникнення або виникнення надзвичайної ситуації та інформування їх про межі поширення, наслідки, способи та методи захисту, а також дії у зоні можливої надзвичайної ситуації; спостереження та контролю за ситуацією на об’єктах, на які поширюється дія цієї постанови, територіях цих об’єктів та/або за їх межами, а також здійснення постійного прогнозування можливості виникнення надзвичайних ситуацій, їх масштабів; уточнення та здійснення заходів щодо захисту населення i територій у разі виникнення надзвичайних ситуацій; готовності наявних 
сил і засобів цивільного захисту, можливість залучення додаткових сил і засобів у разі виникнення надзвичайних ситуацій; створення і використання матеріальних резервів для запобігання виникненню надзвичайних ситуацій і ліквідації їх наслідків тощо. Наказом Міністерства регіонального розвитку, будівництва та житлово-комунального господарства від 19.07.2017 № 175 «Про затвердження Положення про функціональну підсистему безпеки у сфері експлуатації об'єктів житлово-комунального господарства єдиної державної системи цивільного захисту», зареєстрованого в Міністерстві юстиції 09.08.2017 р. за № 972/30840, визначено мету, завдання, організацію управління, склад сил і засобів, порядок їх взаємодії та діяльності функціональної підсистеми безпеки у сфері експлуатації об'єктів житлово-комунального господарства єдиної державної системи цивільного захисту та ін.

\section{5. Управління ризиками на підприємствах водопостачання та водовідведення. Процедурні питання}

Процес управління ризиками на підприємстві $є$ невід’ємною складовою управлінських рішень, і складається з наступних етапів: інформаційно-аналітичний етап передбачає постійний моніторинг факторів зовнішнього середовища та підприємства. На даному етапі здійснюється збирання, обробка, передавання та аналіз різного роду інформації, що допомагає оцінити можливість виникнення максимально широкого кола ризиків підприємства; визначення контексту ризику включає постановку стратегічних і тактичних цілей підприємства; якісний аналіз ризику передбачає виявлення чинників створювання ризиків, ідентифікацію можливих ризиків, наслідків їх реалізації для підприємства (вплив на його цілі); кількісний аналіз ризику включає оцінку рівня ризику і рівня впливу на діяльність підприємства $[18 ; 33]$.

Аналіз закордонних досліджень та керівних практик щодо управління ризиками в сфері водопостачання та водовідведення, щодо оцінки та аналізу ризиків, щодо складання планів безпечного водопостачання дозволяє визначити, що основним елементом цих документів є розробка планів систематичного аналізу ризиків на усіх етапах водопостачання від водозабору, очищення, відкачування, зберігання і до розподілу води, 3 метою забезпечення безпеки споживачів води [5; 8; 13; 42; 43]. На підставі проведеного аналізу можна запропонувати модульне управління ризиками для підприємств водопостачання та водовідведення (рис. 1). 
Chapter «State administration»

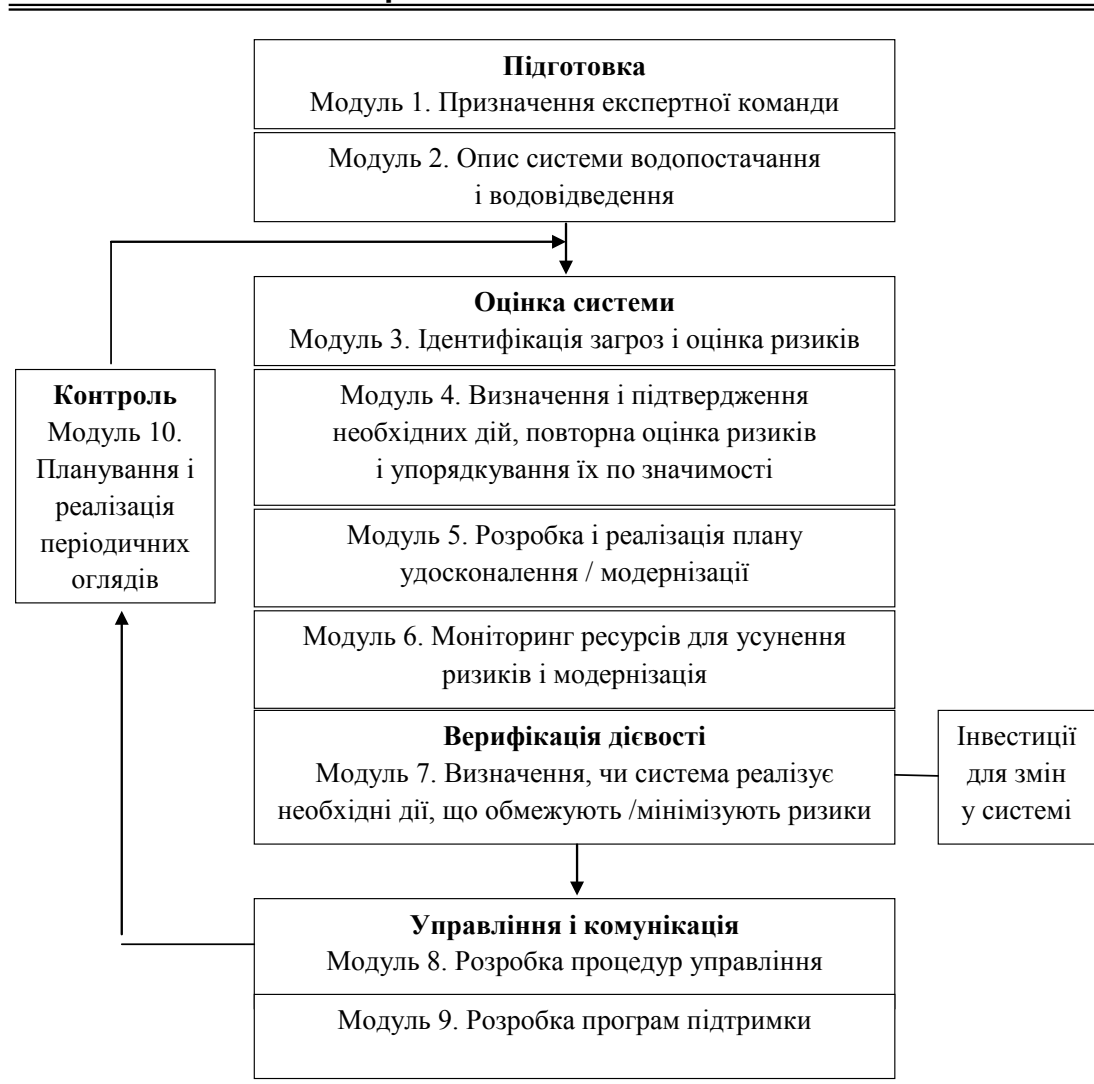

\section{Рис. 1. Система управління ризиками на підприємстві водопостачання і водовідведення}

Джерело: створено за [13; 5; 8; 42; 43]

Модуль 1. Створення експертної команди. Утворення команди кваліфікованих експертів $є$ першою умовою для формування системи управління ризиками. На команду покладаються обов'язки і відповідальність за ідентифікацію загроз, які можуть мати вплив на якість води і безпеку водопостачання та водовідведення, а також вибір рішень для їх усунення / мінімізацію.

Модуль 2. Опис системи водопостачання і водовідведення. Першим завданням команди є повний опис системи водопостачання і водовід- 
ведення. Докладний опис системи потрібний з огляду на його використання в процесі оцінки ризику. Він повинен включати інформацію, достатню для ідентифікації загроз (їх видів і місць), а також відповідних запобіжних заходів.

Модуль 3. Ідентифікація загроз і оцінка ризиків. На практиці модуль 3 реалізовуються одночасно з модулем 4 (Визначення і підтвердження необхідних дій, повторна оцінка ризиків і упорядкування їх по значимості) і модулем 5 (Розробка і реалізація плану удосконалення / модернізацій). Під ідентифікацією ризику розуміється діяльність, спрямована на виявлення самого факту існування ризику і визначення його природи. Модуль має вирішити завдання: ідентифікувати всі зовнішні потенційні біологічні, фізичні і хімічні загрози, пов'язані з окремими етапами водопостачання та водовідведення, які можуть вплинути на безпеку; ідентифікувати всі внутрішні загрози і небезпеки, що можуть привести до забруднення водопроводу, обмеження його дії або перерви в доставці води; оцінити ризики по кожному елементу, пов'язані з кожною загрозою, описати ймовірність їх виникнення (наприклад, «дуже ймовірна», «ймовірна», «малоймовірна»), також оцінити наслідки виникнення такої загрози (наприклад, «несуттевий», «суттєвий», «критичний», «катастрофічний»).

Оцінка ризиків зводиться до оцінки ймовірності (частоти) виникнення небезпеки, прогнозування ймовірних втрат і їх вартісного вираження [42]. При цьому можна використати матрицю ризиків (рис. 2).

Ймовірність виникнення загроз оцінюється, спираючись на історичний досвід: рідкісна (неймовірна) - загроза може наступити тільки у виняткових обставинах; не виключена - існує мало реальних шансів, щоб випадок міг настати; малоймовірна - загроза може трапитися у якийсь час; ймовірна - загрозливі випадки мали місце у минулому i задокументовані, існують умови, що сприяють його виникненню; дуже імовірна - загроза наступає регулярно і задокументована, $є$ велика ймовірність їі щорічного виникнення.

Для класифікації наслідків загроз можна застосувати якісний (описовий) механізм, причому слід добирати параметри, наближені до реальності. Кількісну оцінку ризиків отримують за допомогою математично-статистичних методів.

В таблиці 2 наводиться приклад ідентифікації загроз і оцінки виникнення екологічних, виробничих, соціальних ризиків для підприємства сфери водопостачання і водовідведення (табл. 2). 


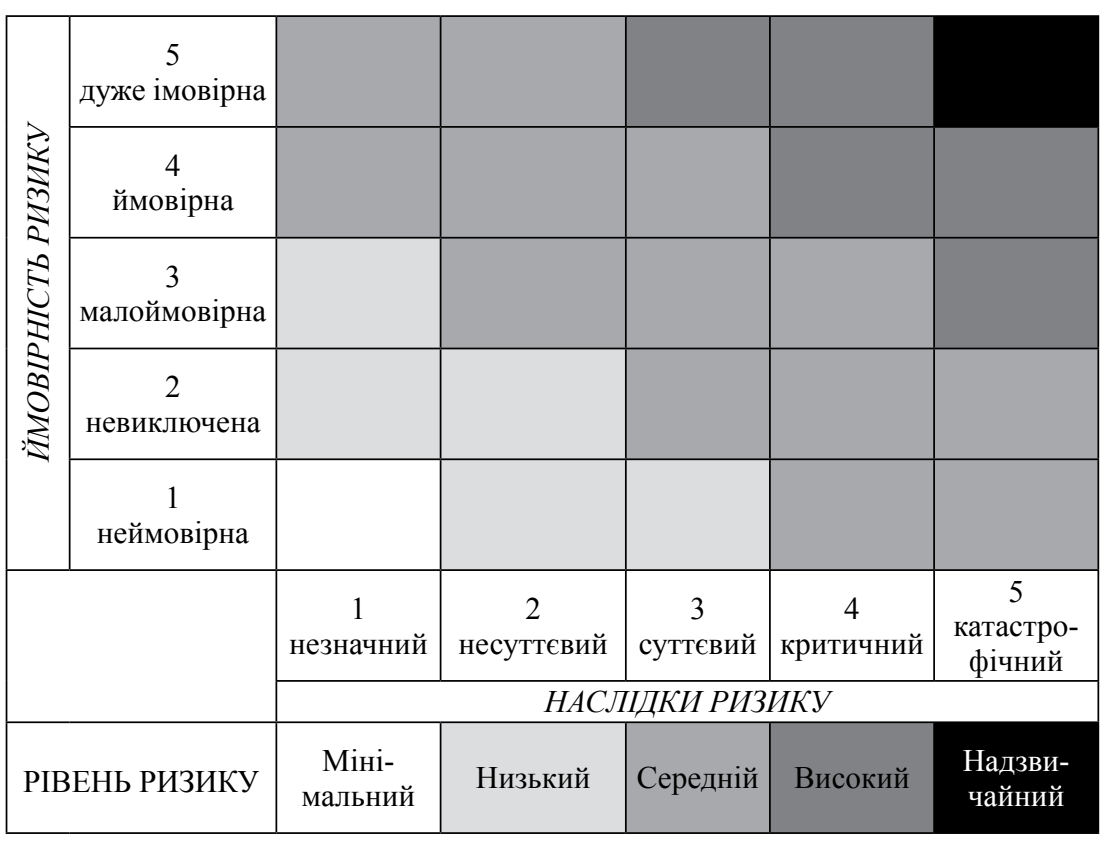

Рис. 2. Матриця визначення рівня ризиків, що можуть виникнути в системі водопостачання та водовідведення

Джерело: створено на основі [42]

Таким чином, для сфери водопостачання і водовідведення високий рівень становлять загрози від інтенсивних дощів і повеней. Інтенсивні дощові опади і паводки - одні з найбільш розповсюджених природних загроз, природне явище, що має надзвичайний характер, часто екстремальний, проявляється регулярно. Ці загрози на території України виникають перш за все в результаті довготривалих і інтенсивних опадів в літній і осінній період, під час швидкої весняної відлиги. Наслідками таких ризиків $\epsilon$ загроза забруднення водозаборів питної води і прибудинкових криниць; загроза забруднення мереж питної води, очисних споруд; знищення і збитки в комунальній інфраструктурі стосуються каналізаційної і водопровідної мережі; необхідність великих капіталовкладень, пов'язаних з ліквідацією наслідків ситуації; можливе місцеве забруднення середовища в результаті пошкодження технічних пристроїв і витоку шкідливих речовин; тощо. 
Таблиця 2

Загрози, які можуть викликати порушення водопостачання. Оцінка ризику їх виникнення

\begin{tabular}{|c|c|c|c|c|}
\hline $\begin{array}{c}\text { Фактори } \\
\text { ризику } \\
\end{array}$ & Загрози & Ймовірність & $\begin{array}{c}\text { Наслідки } \\
\text { ризику }\end{array}$ & $\begin{array}{l}\text { Рівень } \\
\text { ризику }\end{array}$ \\
\hline \multirow{5}{*}{ Екологічні } & $\begin{array}{l}\text { Інтенсивні дощові } \\
\text { опади, повені }\end{array}$ & Дуже ймовірна & Суттєвий & Високий \\
\hline & $\begin{array}{l}\text { Сильні морози і } \\
\text { інтенсивні опади } \\
\text { снігу }\end{array}$ & Ймовірна & Несуттєвий & Середній \\
\hline & Посуха і спека & Ймовірна & Суттєвий & Середній \\
\hline & Епідемії & Малоймовірна & Суттєвий & Низький \\
\hline & Епізоотії & Малоймовірна & Суттєвий & Низький \\
\hline \multirow{5}{*}{ Виробничі } & Хімічне забруднення & Ймовірна & Суттєвий & Середній \\
\hline & \begin{tabular}{|l} 
Біологічне \\
забруднення \\
\end{tabular} & Ймовірна & Суттєвий & Середній \\
\hline & $\begin{array}{l}\text { Радіаційне } \\
\text { забруднення } \\
\end{array}$ & Малоймовірна & Критичний & Середній \\
\hline & Виробничі аварії & Дуже ймовірна & Несуттєвий & Середній \\
\hline & $\begin{array}{l}\text { Порушення в } \\
\text { електропостачанні }\end{array}$ & Ймовірна & Несуттєвий & Середній \\
\hline \multirow[b]{2}{*}{ Соціальні } & Суспільні протести & Малоймовірна & Незначний & Низький \\
\hline & $\begin{array}{l}\text { Терористичні } \\
\text { загрози } \\
\end{array}$ & Не виключена & Катастрофічний & Середній \\
\hline
\end{tabular}

Середній рівень ризику для підприємств водопостачання і водовідведення становить хімічне забруднення - це забруднення повітря, води, грунту, предметів тощо шкідливими речовинами. Забруднення може бути спричинене, наприклад, через застосування отруйних речовин, внаслідок катастрофи або бути постійним результатом деяких промислових процесів, сільськогосподарських, транспортних тощо. Причинами може бути: аварія на підприємствах, які виробляють і зберігають небезпечні хімічні речовини; людська помилка, діяльність/ бездіяльність, халатність, випадок розгерметизації ємкостей з хімічними речовинами; недотримання протипожежних правил; природна катастрофа; терористичний акт; катастрофа під час транспортування небезпечних хімічних речовин, спричинена людською помилкою, недотриманням правил, складними метеорологічними умовами, випадком, поганим станом доріг, технічним станом транспортних 


\section{Chapter «State administration»}

засобів або недоліками залізничних перевезень; аварія транспортних трубопроводів, спричинена людською помилкою, інженерною помилкою, ослабленням витривалості матеріалу; нелегальне складування відходів і місць утилізації виробничих відходів, тощо. Загрози хімічного забруднення: можливість забруднення джерел води або водопровідної мережі; забруднення грунту, повітря, поверхневої води, водозаборів; безпосередня загроза для життя і здоров'я осіб; неможливість доступу до питної води; можлива ізоляція територій, тощо.

Процес оцінки ризику вимагає визначення вірогідності і розміру втрат в результаті різних несприятливих подій, які представляють загрозу для цієї системи.

Модуль 4. Визначення і підтвердження необхідних дій, повторна оцінка ризиків і упорядкування їх по значимості. Паралельно до ідентифікації загроз і оцінки ризику слід визначити існуючі та потенційні «ресурси безпеки». «Ресурси безпеки» («бар'єри», «обмежуючі ресурси») Це дії і процеси, що стосуються зменшення або обмеження ризику. До ресурсів безпеки відносяться короткострокові (наприклад, обмеження або тимчасове призупинення користування даним джерелом води), середньострокові (наприклад, прикриття джерел води) і довгострокові обмежуючі ресурси (наприклад, удосконалення очищення: коагуляція, фільтрація). Зменшення ризиків, досягнуте завдяки окремим ресурсам, буде свідчити про їх дієвість.

Модуль 5. Розробка і реалізація плану удосконалення. Плани удосконалення можуть включати коротко-, середньо- і довгострокові програми. Впровадження планів удосконалення має контролюватися з метою підтвердження впровадження і ефективності результатів. Результатами мають стати: розробка впорядкованого по значимості плану удосконалень для кожного значущого ризику; впровадження плану удосконалень згідно із встановленим графіком коротко-, середньо- або довгострокових дій; контроль впровадження плану удосконалень.

Модуль 6. Моніторинг ресурсів для усунення ризиків і модернізації (операційний моніторинг). Полягає в тому, щоб визначити і підтвердити ресурси безпеки, а також в розробці процедур, які засвідчать дієвість цих ресурсів і необхідних коригуючих дій в ситуації, коли операційні цілі не реалізовуються.

Модуль 7. Верифікація дієвості. Це процес визначення, чи система реалізує необхідні дії, що обмежують / мінімізують ризики. Він склада- 
ється з трьох дій: моніторинг узгодження; внутрішній і зовнішній аудит операційної діяльності; визначення рівня задоволеності споживачів. Верифікація має підтвердити, що загальна модель системи дієва і дозволить забезпечити безперервне постачання води необхідної якості.

Модуль 8. Розробка процедур управління. Процедури управління визначають операції щодо постачання води в нормальних умовах, а також описують кроки, які слід здійснити під час кризових ситуацій, коли може наступити втрата контролю над системою. Важливою частиною Модуля $8 \epsilon$ розробка коригуючих дій, які визначають конкретні операційні реакції в ситуації відхилень від встановлених планів.

Модуль 9. Розробка програм підтримки. Це дії, які підтримують розвиток вмінь і знань персоналу, здатність управляти системами 3 метою виконання основного завдання - постачання безпечної для споживання води. Програми пов'язуються з дослідженнями і можуть включати дії, які підтримують безпеку води, наприклад по оптимізації таких процесів як збільшення контролю якості в лабораторіях.

Модуль 10. Планування і реалізація періодичних оглядів. Після виникнення кризової або загрозливої ситуації слід зробити повторну оцінку ризику, яку потрібно буде врахувати в плані модернізації доставки безпечної для споживання води. Потрібна регулярна підтримка контакту зі споживачами води. Актуалізований план безпечної води має відповідати потребам підприємства і водозабезпечення споживачів.

Підприємство водопостачання і водовідведення має забезпечити розробку та впровадження системи управління власними ризиками, задля забезпечення безпечного водопостачання та водовідведення. Разом 3 тим, інші суб'єкти (суб'єкти господарювання, суб'єкти отримання послуг тощо) теж несуть відповідальність за безпечність водопостачання і мають бути задіяні в цьому процесі. Таким чином, державна політика у сфері водопостачання та водовідведення має передбачати систему управління ризиками та забезпечення безпечного водопостачання та водовідведення.

\section{6. Висновки}

Безпечне водопостачання та водовідведення давно вийшло за рамки забезпечення якості питної води. Це стан функціонування сфери водопостачання та водовідведення, водної інфраструктури країни, за якого усі споживачі повинні мати постійний безперебійний доступ до 


\section{Chapter «State administration»}

послуг водопостачання та водовідведення у прийнятній кількості та якості для здоров'я, засобів до існування та виробництва у поєднанні 3 прийнятним рівнем можливих ризиків. 3 метою впровадження на підприємствах водопостачання та водовідведення системи управління ризиками, пов'язаними 3 загрозами безпечного водопостачання та водовідведення, держава має передбачити серед принципів державної політики безпечне водопостачання та водовідведення і запровадити систему управління ризиками, пов'язаними з зазначеними загрозами. При цьому, система управління ризиками, пов'язаними з загрозами безпечного водопостачання та водовідведення повинна передбачати ідентифікацію, аналіз та визначення ступеню ризиків, пов'язаних 3 загрозами, ідентифікацію ймовірних наслідків, причин їх настання та сценаріїв розвитку, систему моніторингу та застосування заходів попередження та/або мінімізації негативних наслідків.

\section{Список літератури:}

1. BASEL II / BASEL III. URL: https://www.fincad.com/resources/-learningresources/regulations/basel-ii-basel-iii (дата звернення: 15.02.2019).

2. Claudia Copeland (2010). Terrorism and Security Issues Facing the Water Infrastructure Sector. URL: https://fas.org/sgp/crs/terror/RL32189.pdf (дата звернення: 15.02.2019).

3. COSO ERM. URL: https://www.pwc.ru/coso-erm (дата звернення: 15.02.2019).

4. David Grey \& Claudia W. Sadoff. «Sink or Swim? Water security for growth and development» // Water Policy. 2007. - P. 545-571. URL: http://cip.management.dal.ca/publications/Water $\% 20$ security $\% 20$ for $\% 20$ growth\%20and\%20development.pdf/ (дата звернення: 15.02.2019).

5. Fajrul Falakh, Onny Setiani (2018). Hazard Identification and Risk Assessment in Water Treatment Plant considering Environmental Health and Safety Practice. URL: https:/www.e3s-conferences.org/articles/e3sconf/abs/2018/06/e3sconf icenis2018_06011/e3sconf_icenis2018_06011.htm (дата звернення: 15.02.2019).

6. FERMA. URL: https://www.ferma.eu/\#header (дата звернення: 15.02.2019).

7. Global Water Partnership, 2000. URL: https://www.gwp.org/en/About/why/ the-water-challenge/ (дата звернення: 15.02.2019).

8. Hokstad P., Røstum J., Sklet S., Rosén L., Pettersson T.J.R. Methods for risk analysis of drinking water systems from source to tap - Guidance report on Risk Analysis.URL:http://citeseerx.ist.psu.edu/viewdoc/-download?doi=10.1.1.367.4044$\& r e p=$ rep1\&type=pdf (дата звернення: 15.02.2019).

9. IRM's risk management standard. URL: https://www.theirm.org/the-riskprofession/risk-management/irms-risk-management-standard.aspx (дата звернення: 15.02.2019). 


\section{Krylova Iryna}

10. ISO 31000 ISO/TR 31004:2013 Risk management - Guidance for the implementation of ISO 31000. URL: https://www.iso.org/standard/56610.html (дата звернення: 15.02.2019).

11. ISO Guide 73: 2009 «Risk management - Vocabulary - Guidelines for use in standards». URL: https://www.iso.org/standard/44651.html (дата звернення: 15.02.2019).

12. Terry J.V. Distionary for business and finance. - London, 1989. - 97 p.

13. Water Safety Plan Manual (Step-by-step risk management for drinkingwater suppliers). URL: http://apps.who.int/iris/bitstream/handle/10665/75141/ -9789241562638_eng.pdf?sequence=1 (дата звернення: 15.02.2019).

14. Water safety planning. World Health Organization. URL: https:/www.who.int/ water sanitation health/water-quality/safety-planning/en/ (дата звернення: 15.02.2019).

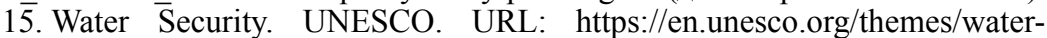
security (дата звернення: 15.02.2019).

16. Андріяш B.I. Державна політика: концептуальні аспекти визначення // Державне управління: удосконалення та розвиток. - 2013. - № 9. URL: http://www.dy.nayka.com.ua/?op=1\&z=626 (дата звернення: 15.02.2019).

17. Васильєв О.С. Концептуалізація поняття «державна політика»: сучасне розуміння // Державне будівництво. - 2014. - № 1. - С. 1-10.

18. Гришнякова К.Г., Кузьменко В.В. Організація управління ризиком на підприємстві. URL: http://www.rusnauka.com/10_NPE_2011/ Economics/-10_83060.doc.htm (дата звернення: 15.02.2019).

19. Державна політика: підручник / Нац. акад. держ. упр. при Президентові України; ред. кол.: Ю.В. Ковбасюк (голова), К.О. Ващенко (заст. голови), Ю.П. Сурмін (заст. голови) [та ін.]. - К.: НАДУ, 2014. - 448 с.

20. Директива о предотвращении тяжелых аварий (Севезо III). URL: http://phase1.pprdeast2.eu/assets/files/Publications/SevesoIII_Directive_ RUS.pdf (дата звернення: 15.02.2019).

21. Донець Л.І. Економічні ризики та методи їх вимірювання: навч. Посібник. - К.: Центр навчальної літератури, 2006. - 312 с. URL: http://www.dut.edu.ua/uploads/1_1400_92168184.pdf (дата звернення: 15.02.2019).

22. ДСТУ ISO 31000:2014 «Менеджмент ризиків. Принципи та керівні вказівки». URL: http://document.ua/menedzhment-rizikiv_-principi-ta-kerivnivkazivki-std31058.html (дата звернення: 15.02.2019).

23. ДСТУ ISO Guide 73:2013 «Керування ризиком. Словник термінів». URL: http://metrology.com.ua/download/iso-iec-ohsas-i-dr/61-iso/325-dstu-isoguide-73-2013 (дата звернення: 15.02.2019).

24. ДСТУ ISO/IEC 31010:2013 «Керування ризиком. Методи загального оцінювання ризику». URL: http://metrology.com.ua/download/iso-iec-ohsas-i$\mathrm{dr} / 87$-eea/1062-dstu-ies-iso-31010-2013 (дата звернення: 15.02.2019).

25. Дядюк М.А. Управління ризиками. Конспект лекцій. Харків. - 2017. - 165 c. URL: http://elib.hduht.edu.ua/bitstream/123456789/1893 /1/125 \%D0-\%A3\%D0\%A0\%20\%D0\%9A\%D0\%BE\%D0\%BD\%D1\%81\%D0\% BF\%D0\%B5\%D0\%BA\%D1\%82\%20\%D0\%BB\%D0\%B5\%D0\%BA\%D1\%86\% D0\%B8\%D0\%B9\%20\%D1\%87.1.pdf (дата звернення: 15.02.2019). 


\section{Chapter «State administration»}

26. Економічний ризик: методи оцінки та управління: навч. посібник / Т. А. Васильєва, С. В. Лєонов, Я. М. Кривич та ін.; під заг. ред. Т. А. Васильєвої, Я. М. Кривич. - Суми: ДВНЗ «УАБС НБУ», 2015. - 208 с. URL: https://essuir.sumdu.edu.ua/bitstream/123456789/50229/5/Ekonomichnyi_ ryzyk\%20.pdf (дата звернення: 15.02.2019).

27. Енциклопедичний словник 3 державного управління. За редакцією Ю. В. Ковбасюка, В. П. Трощинського, Ю. П. Сурміна. - К.: НАДУ, 2010. - 820 с. URL: http://academy.gov.ua/NMKD/library_nadu/Encycloped_vydanniy/14ff57eb06bd-4b2b-8bfb-ead7f286d5dd.pdf (дата звернення: 15.02.2019).

28. Загальнодержавна цільова програма «Питна вода України» на 2011-2020 роки. Закон України від 20.10.2011 р. № 3933-VI. База даних: «Верховна рада України». URL: http://zakon.rada.gov.ua/laws/show/2455-15/ ed20111113 (дата звернення: 15.02.2019).

29. Клименко С.М. Обгрунтування господарських рішень та оцінка ризиків: Навч. посібник. - К.: КНЕУ, 2005. - 252 с. URL: http://ubooks.com.ua/ books/000271/inx.php (дата звернення: 15.02.2019).

30. Клочко Е.А.Оценка и управление экологическими рисками системы городского водоснабжения и водоотведения // Коммунальное хозяйство городов. Научно-технический сборник. - 2009. - № 86. - С. 408-412. URL: http://eprints.kname.edu.ua/11447/ (дата звернення: 15.02.2019).

31. Коновалов Ю.О., Миронов О.В. Система управління ризиками: поняття, функції, компоненти // Інноваційна економіка. - 2013. - № 9. - С. 127-132. URL: file:///C:/Users/original/Downloads/inek_2013_9_20\%20(1).pdf (дата звернення: 15.02.2019).

32. Логвінова О. П. Обгрунтування господарських рішень i оцінювання ризиків: навч. посіб. - Х.: Вид-во «Лідер», 2015. - 370 с. URL: https://pidruchniki.com/86383/ekonomika/vidi_riziku_diyalnosti_pidpriyemstv\#51/ (дата звернення: 15.02.2019).

33. Мостенська Т.Л., Скопенко Н.С. Ризик-менеджмент як інструмент управління господарським ризиком підприємства // Вісник Запорізького національного університету. - 2010. - № 3(7). - С. 72-79. URL: http://web.znu.edu.ua/herald/issues/2010/Vest_Ek7-3-2010-PDF/072-79.pdf (дата звернення: 15.02.2019).

34. Національна доповідь про якість питної води та стан питного водопостачання в Україні у 2016 році. База даних «Мінрегіон України». URL:http://www.minregion.gov.ua/napryamki-diyalnosti/zhkh/teplo-vodopostachannyata-vodovidvedennya/natsionalna-dopovid/proekt-natsionalnoyi-dopovidi-proyakist-pitnoyi-vodi-ta-stan-pitnogo-vodopostachannya-v-ukrayini-u-2016-rotsi/ (дата звернення: 01.02.2019).

35. Петренко I. Сутність державної політики та державних цільових програм // Віче. - 2011. - №10. База даних: «Журнал Верховної Ради України «Biче». URL: http://veche.kiev.ua/journal/2566/ (дата звернення: 15.02.2019).

36. Про забезпечення санітарного та епідемічного благополуччя населення: Закон України від 24.02.1994 № 4004-XII. База даних: законодавство України. URL: https://zakon.rada.gov.ua/laws/show/4004-12 (дата звернення: 15.02.2019). 
37. Про затвердження Методики визначення ризиків та їх прийнятних рівнів для декларування безпеки об'єктів підвищеної небезпеки: наказ Міністерства праці та соціальної політики України від 04.12.2002 p. № 637. База даних: Законодавство України. URL: https://zakon.rada.gov.ua/rada/show/v0637203-02?lang=ru (дата звернення: 15.02.2019).

38. Про затвердження Методики оцінки збитків від наслідків надзвичайних ситуацій техногенного і природного характеру: постанова Кабінету Міністрів України від 15.02.2002 р. № 175. База даних: Законодавство України. URL: https://zakon.rada.gov.ua/laws/show/175-2002-\%D0\%BF (дата звернення: 15.02.2019).

39. Про об'єкти підвищеної небезпеки: Закон України від 18.01.2001 №2245-III. База даних: законодавство України. URL: https://zakon.rada.gov.ua/ laws/show/2245-14 (дата звернення: 15.02.2019).

40. Про питну воду, питне водопостачання та водовідведення: Закон від 10.01.2012 p. № 2918-III. База даних «Законодавство України» / ВР України. URL: http://zakon3.rada.gov.ua/laws/show/2918-14 (дата звернення: 15.02.2019).

41. Ролько О. Управління ризиками в системах управління // Стандартизація сертифікація якість. - 2011. - № 1. - C. 47-52. URL: file://C:/Users/-user/ Downloads/ssia_2011_1_15.pdf (дата звернення: 15.02.2019).

42. Руководство Еврокомиссии по оценке и картированию рисков для обеспечения готовности к стихийным бедствиям. URL: http://phase1.pprdeast2. $\mathrm{eu} /$ assets/files/Publications/Risk\%20Assessment\%20and\%20Mapping\%20 Guidelines_EN_RU.pdf (дата звернення: 15.02.2019).

43. Руководство по разработке и реализации плана обеспечения безопасности воды Пошаговое управление рисками для поставщиков питьевой воды. URL: https://apps.who.int/iris/bitstream/handle/10665/87662/-9789244562635_ rus.pdf?sequence=1 (дата звернення: 15.02.2019).

44. Сидорук Н.Л. Система управління економічними ризиками господарської діяльності підприємства // Економічні науки. Економіка підприємства. 2010. URL: http://www.rusnauka.com/17 AND 2010/Economics/-69266.doc.htm (дата звернення: 15.02.2019).

45. Синки Дж. Финансовый менеджмент в коммерческом банке и в индустрии финансовых услуг. - М.: Альпина Бизнес Букс, 2007. URL: http://virtua.nsaem.ru:8001/mm/2008/000096859.pdf (дата звернення: 15.02.2019).

46. Словник української мови. URL: http://sum.in.ua/s/rysk (дата звернення: 15.02.2019).

47. Сутність ризиків у діяльності підприємства. URL: http://ukr.vipreshebnik.ru/ upr-rizik/3993-sutnist-rizikiv-u-diyalnosti-pidpriemstva.html (дата звернення: 15.02.2019).

48. Тертичка В. Державна політика: аналіз та здійснення в Україні. - К.: Видавництво Соломії Павличко «Основи». - 2002. - 750 с. URL: $\quad$ https://moodle.znu.edu.ua/pluginfile.php?file $=/ 180489 / \mathrm{mod}$ resource/ content $/ 1 / \%$ D0\%A2\%D0\%B5\%D $1 \% 80 \% \mathrm{D} 1 \% 82 \% \mathrm{D} 0 \% \mathrm{~B} 8 \% \mathrm{D} 1 \% 8 \overline{7} \% \mathrm{D} 0 \% \mathrm{~B}$ A $\%$ D0\%B0\% $20 \% \mathrm{D} 0 \% 92 . \% 20 \% \mathrm{D} 0 \% 94 \% \mathrm{D} 0 \% \mathrm{~B} 5 \% \mathrm{D} 1 \% 80 \% \mathrm{D} 0 \% \mathrm{~B} 6 \% \mathrm{D} 0 \%$ B0\%D0\%B2\%D0\%BD\%D0\%B0\%20\%D0\%BF\%D0\%BE\%D0\%BB $\%$ D $1 \% 9-$ $6 \% \mathrm{D} 1 \% 82 \% \mathrm{D} 0 \% \mathrm{~B} 8 \% \mathrm{D} 0 \% \mathrm{BA} \% \mathrm{D} 0 \% \mathrm{~B} 0 \% 20 \% \mathrm{D} 0 \% \mathrm{~B} 0 \% \mathrm{D} 0 \% \mathrm{BD} \% \mathrm{D} 0 \% \mathrm{~B} 0$ 


\section{Chapter «State administration»}

$\%$ D0 $\%$ BB $\%$ D $1 \% 96 \%$ D0 $\%$ B $7 \% 20 \%$ D $1 \% 82 \%$ D0\%B0\%20\%D0\%B7\%D0\%B $4 \% \mathrm{D} 1 \% 96 \% \mathrm{D} 0 \% \mathrm{~B} 9 \% \mathrm{D} 1 \% 81 \% \mathrm{D} 0 \% \mathrm{BD} \% \mathrm{D} 0 \% \mathrm{~B} 5 \% \mathrm{D} 0 \% \mathrm{BD} \% \mathrm{D} 0 \% \mathrm{BD} \% \mathrm{D} 1$ $\% 8 \mathrm{~F} \% 20 \% \mathrm{D} 0 \% \mathrm{~B} 2 \% 20 \% \mathrm{D} 0 \% \mathrm{~A} 3 \% \mathrm{D} 0 \% \mathrm{BA} \% \mathrm{D} 1 \% 80 \% \mathrm{D} 0 \% \mathrm{~B} 0 \% \mathrm{D} 1 \% 97 \% \mathrm{D} 0 \%$ $\mathrm{BD} \% \mathrm{D} 1 \% 96 . p d f$ (дата звернення: 15.02.2019).

49. Тэпман Л.Н. Риски в экономике. Уч.пособие для вузов / под ред. В.А. Швадара. - М.: ЮНИТИ-ДАНА. - 2002. - 380 с. URL: https://studfiles.net/ preview/-1099586/ (дата звернення: 15.02.2019).

50. Цабієв О.М. Екологічна безпека. Конспект лекцій. - Одеса: Наука і техніка. - Одеса, 2009. - 139 с.

\section{References:}

1. BASEL II / BASEL III. Retrieved from: https:/www.fincad.com/resources/learning-resources/regulations/basel-ii-basel-iii

2. Claudia Copeland (2010). Terrorism and Security Issues Facing the Water Infrastructure Sector. Retrieved from: https://as.org/sgp/crs/terror/RL32189.pdf

3. COSO ERM. Retrieved from: https://www.pwc.ru/coso-erm

4. David Gray \& Claudia W. Sadoff. (2007). Sink or Swim? Water security for growth and development. Water Policy. - P. 545-571. Retrieved from: http://cip.management.dal.ca/publications/Water $\% 20$ security $\% 20$ for $\% 20$ growth\%20and\%20development.pdf/

5. Fajrul Falakh, Onny Setiani (2018). Hazard Identification and RiskAssessment in Water Treatment Plant considering Environmental Health and Safety Practice. Retrieved from: https:/www.e3s-conferences.org/articles/-e3sconf/abs/2018/06/ e3sconf icenis2018 06011/e3sconf icenis2018 06011.htm

6. FËRMA. Retrieved from: https://www.ferma.eu/\#header

7. Global Water Partnership, 2000. Retrieved from: https://www.gwp.org/en/ About/why/the-water-challenge/

8. Hokstad P., Røstum J., Sklet S., Rosén L., Pettersson T.J.R. Methods for risk analysis of drinking water systems from source to tap - Guidance report on Risk Analysis. Retrieved from: http://citeseerx.ist.psu.edu/viewdoc/download?doi=10.1.1.367.4044-\&rep=rep1\&type $=$ pdf

9. IRM's risk management standard. Retrieved from: https://www.theirm.org/ the-risk-profession/risk-management/irms-risk-management-standard.aspx

10. ISO 31000 ISO/TR 31004:2013 Risk management - Guidance for the implementation of ISO 31000. Retrieved from: https://www.iso.org/standard/56610.html

11. ISO Guide 73: 2009 «Risk management - Vocabulary - Guidelines for use in standards». Retrieved from: https://www.iso.org/standard/44651.html

12. Terry J. V. Distionary for business and finance. - London, 1989. - $97 \mathrm{p}$.

13. Water Safety Plan Manual (Step-by-step risk management for drinkingwater suppliers). Retrieved from: http://apps.who.int/iris/bitstream/-handle/10665/ 75141/9789241562638_eng.pdf? sequence $=1$

14. Water safety planning. World Health Organization. Retrieved from: https:/www.who.int/water_sanitation_health/water-quality/safety-planning/en/

15. Water Security. UN̄ESCO. Retrieved from: https://en.unesco.org/themes/ water-security 
16. Andriiash V.I. (2013). Derzhavna polityka: kontseptualni aspekty vyznachennia. [State Policy: Conceptual Aspects of Definition]. Derzhavne upravlinnia: udoskonalennia ta rozvytok - Public Administration: Improvement and Development, 9. Retrieved from: http://www.dy.nayka.com.ua/?op=1\&z=626

17. Vasyliev O.S. (2014). Kontseptualizatsiia poniattia «derzhavna polityka»: suchasne rozuminnia. [Conceptualization of the concept of «state policy»: a modern understanding]. Derzhavne budivnytstvo - State construction, 1, 1-10. (in Ukrainian)

18. Hryshniakova K.H., Kuzmenko V.V. (2011). Orhanizatsiia upravlinnia ryzykom na pidpryiemstvi. [Organization of risk management at an enterprise]. Retrieved from: http://www.rusnauka.com/-10_NPE_2011/Economics/-10_ 83060.doc.htm. (in Ukrainian)

19. Kovbasiuk Yu.V., Vashchenko K.O., Surmin Yu. P. (2014). Derzhavna polityka: pidruchnyk. [State policy: Textbook]. (p. 448). K.: NADU. (in Ukrainian)

20. Direktiva o predotvraschenii tyazhelyih avariy (Sevezo III). Retrieved from: http://phase1.pprdeast2.eu/assets/files/Publications/SevesoIII_Directive-_RUS.pdf (in Russian)

21. Donets L.I. (2006). Ekonomichni ryzyky ta metody yikh vymiriuvannia: navch. Posibnyk. [Economic risks and methods of their measurement: Textbook]. (p. 312). - K.: Tsentr navchalnoi literatury. Retrieved from: http://www.dut.edu.ua/ uploads/1_1400_92168184.pdf (in Ukrainian)

22. DSTU ISO 31000:2014 «Menedzhment ryzykiv. Pryntsypy ta kerivni vkazivky». [DSTU ISO 31000: 2014 "Risk Management. Principles and guidelines"]. Retrieved from: http://document.ua/menedzhment-rizikiv_-principita-kerivni-vkazivki-std31058.html (in Ukrainian)

23. DSTU ISO Guide 73:2013 «Keruvannia ryzykom. Slovnyk terminiv». [DSTU ISO Guide 73: 2013 "Risk Management. Glossary of Terms"]. Retrieved from: http://metrology.com.ua/download/iso-iec-ohsas-i-dr/61-iso/325-dstu-iso-guide73-2013 (in Ukrainian)

24. DSTU ISO/IEC 31010:2013 «Keruvannia ryzykom. Metody zahalnoho otsiniuvannia ryzyku». [DSTU ISO / IEC 31010:2013 "Risk Management. Methods of general risk assessment"]. Retrieved from: http://metrology.com.ua/download/ iso-iec-ohsas-i-dr/87-eea/1062-dstu-ies-iso-31010-2013 (in Ukrainian)

25. Diadiuk M.A. (2017). Upravlinnia ryzykamy. Konspekt lektsii. [Risk Management. Summary of lectures]. (p. 165). - Kharkiv. Retrieved from: http://elib.hduht.edu.ua/bitstream/123456789/1893/1/125\%D0-\%A3\%D0\%A0\% $20 \%$ D $0 \% 9$ A $\%$ D $0 \%$ BE $\%$ D $0 \%$ BD $\%$ D $1 \% 81 \%$ D $0 \%$ B F $\%$ D $0 \%$ B $5 \%$ D $0 \%$ BA $\%$ D $1 \% 82 \% 20 \%$ D0\%BB $\%$ D0\%B $0 \%$ D0\%BA\%D $1 \% 86 \%$ D $0 \%$ B $8 \%$ D0 $\% \mathrm{~B} 9 \% 20 \% \mathrm{D} 1 \% 87.1$.pdf (in Ukrainian)

26. Vasylieva T.A., Lieonov S.V., Kryvych Ya.M. (2015). Ekonomichnyi ryzyk: metody otsinky ta upravlinnia: navch. posibnyk. [Economic risk: methods of evaluation and management: Textbook]. (p.208). - Sumy: DVNZ «UABS NBU». Retrieved from: https://essuir.sumdu.edu.ua/bitstream/123456789/50229/-5/ Ekonomichnyi ryzyk\%20.pdf (in Ukrainian)

27. Kovbasiuk Yu.V., Troshchynskiy V.P., Surmin Yu.P. (2010). Entsyklopedychnyi slovnyk $\mathrm{z}$ derzhavnoho upravlinnia. [Encyclopedic Dictionary of Public 


\section{Chapter «State administration»}

Administration]. (p. 820). K.: NADU. Retrieved from: http://academy.gov.ua/NMKD/ library_nadu/Encycloped_vydanniy/14ff57eb-06bd-4b2b-8bfb-ead7f286d5dd.pdf (in Ukrainian)

28. Zakon Ukrainy «Zahalnoderzhavna prohrama «Pytna voda Ukrainy» na 2011-2020 roky» vid 20.10.2011 № 3933-VI. [Law of Ukraine “On Approval of the National Target Program" Drinking Water of Ukraine "for 2011-2020"]. Retrieved from: http://zakon.rada.gov.ua/laws/show/2455-15/ed20111113 (in Ukrainian)

29. Klymenko S.M. (2005). Obgruntuvannia hospodarskykh rishen ta otsinka ryzykiv: Navch. Posibnyk. [Rationale for business decisions and risk assessment: Textbook]. (p. 252). K.: KNEU. Retrieved from: http://ubooks.com.ua/books/000271/inx.php (in Ukrainian)

30. Klochko E.A. (2009). Otsenka i upravlenie ekologicheskimi riskami sistemyi gorodskogo vodosnabzheniya i vodootvedeniya. [Assessment and management of environmental risks of the city water supply and water disposal system]. Kommunalnoe hozyaystvo gorodov. Nauchno-tehnicheskiy sbornik Utilities of cities. Scientific and technical collection, 86, 408-412. Retrieved from: http://eprints.kname.edu.ua/11447/ (in Russian)

31. Konovalov Yu.O., Myronov O.V. (2013). Systema upravlinnia ryzykamy: poniattia, funktsii, komponenty. [Risk Management System: Concept, Functions, Components]. Innovatsiina ekonomika - Innovative Economics, 9, 127-132. Retrieved from: file://C:/Users/original/Downloads/inek_2013_9_20\%20(1).pdf (in Ukrainian)

32. Lohvinova O.P.(2015). Obgruntuvannia hospodarskykh rishen i otsiniuvannia pyzykiv: navch. posib. [Justification of economic decisions and evaluation of psychology: Textbook]. (p.370). - Kh.: Vyd-vo «Lider». Retrieved from: https://pidruchniki.com/86383/ekonomika/vidi_riziku_diyalnosti_pidpriyemstv\#51/ (in Ukrainian)

33. Mostenska T.L., Skopenko N.S. (2010). Ryzyk-menedzhment yak instrument upravlinnia hospodarskym ryzykom pidpryiemstva. [Risk management as a tool for business risk management of the enterprise]. Visnyk Zaporizkoho natsionalnoho universytetu - Bulletin of the Zaporizhzhya National University, 3(7), 72-79. Retrieved from: http://web.znu.edu.ua/herald/issues/2010/Vest_Ek7-32010-PDF/072-79.pdf (in Ukrainian)

34. Natsionalnadopovid proyakistpytnoivody tastan pytnohovodopostachannia v Ukraini u 2016 rotsi. (2016). [National report on the quality of drinking water and the state of drinking water supply in Ukraine in 2016]. Retrieved from: http://www.minregion.gov.ua/napryamki-diyalnosti/zhkh/teplovodopostachannya-ta-vodovidvedennya/natsionalna-dopovid/proekt-natsionalnoyidopovidi-pro-yakist-pitnoyi-vodi-ta-stan-pitnogo-vodopostachannya-v-ukrayiniu-2016-rotsi/ (in Ukrainian)

35. Petrenko I. (2011). Sutnist derzhavnoi polityky ta derzhavnykh tsilovykh prohram. [The essence of state policy and state targeted programs]. Viche-Veche, 10. Retrieved from: http://veche.kiev.ua/journal/2566/ (in Ukrainian)

36. Zakon Ukrainy Pro zabezpechennia sanitarnoho ta epidemichnoho blahopoluchchia naselennia vid 24.02.1994 № 4004-XII. [Law of Ukraine on ensuring sanitary and epidemiological well-being of the population]. Retrieved from: https://zakon.rada.gov.ua/laws/show/4004-12 (in Ukrainian) 
37. Nakaz Ministerstva pratsi ta sotsialnoi polityky Ukrainy Pro zatverdzhennia Metodyky vyznachennia ryzykiv ta yikh pryiniatnykh rivniv dlia deklaruvannia bezpeky obiektiv pidvyshchenoi nebezpeky vid 04.12.2002 № 637. [Order of the Ministry of Labor and Social Policy of Ukraine On approval of the Methodology for determining the risks and their acceptable levels for declaring the safety of objects of high danger]. Retrieved from: https://zakon.rada.gov.ua/rada/show/-v063720302?lang=ru (in Ukrainian)

38. Postanova Kabinetu Ministriv Ukrainy Pro zatverdzhennia Metodyky otsinky zbytkiv vid naslidkiv nadzvychainykh sytuatsii tekhnohennoho i pryrodnoho kharakteru: postanova Kabinetu Ministriv Ukrainy vid 15.02.2002 № 175. [Resolution of the Cabinet of Ministers of Ukraine Concerning the Approval of the Methodology for Assessing Damage from the Consequences of Emergencies of Man-made and Natural Characteristics].Retrieved from: https://zakon.rada.gov.ua/ laws/show/175-2002-\%D0\%BF (in Ukrainian)

39. Zakon Ukrainy Pro obiekty pidvyshchenoi nebezpeky vid 18.01.2001 № 2245-III. [Law of Ukraine On Hazardous Objects]. Retrieved from: https://zakon.rada.gov.ua/laws/show/2245-14 (in Ukrainian)

40. Zakon Ukrainy Pro pytnu vodu, pytne vodopostachannia ta vodovidvedennia vid 10.01.2012 r. № 2918-III. [Low of Ukraine on Drinking water, potable water supply and discharge]. Retrieved from: http://zakon3.rada.gov.ua/laws/show/2918-14 (in Ukrainian)

41. Rolko O. (2011). Upravlinnia ryzykamy v systemakh upravlinnia. [Risk Management in Management Systems]. Standartyzatsiia sertyfikatsiia yakist Standardization Quality Certification, 1, 47-52. Retrieved from: file://C:/Users/ -user/Downloads/ssia_2011_1_15.pdf (in Ukrainian)

42. Rukovodstvo Evrokomissii po otsenke i kartirovaniyu riskov dlya obespecheniya gotovnosti k stihiynyim bedstviyam. [Risk Assessment and Mapping Guidelines for Disaster Management]. Retrieved from: http://phase1.pprdeast2.eu/ assets/files/Publications/Risk Assessment and Mapping Guidelines_EN_RU.pdf (in Russian)

43. Bartram J., Corrales L., Davison A., Deere D., Drury D., Gordon B., Howard G., Rinehold A., Stevens M. (2011). Rukovodstvo po razrabotke i realizatsii plana obespecheniya bezopasnosti vodyi Poshagovoe upravlenie riskami dlya postavschikov pitevoy vodyi. [Water safety plan manual: step-by-step risk management for drinking-water suppliers]. Retrieved from: https://apps.who.int/ iris/bitstream/handle/10665/87662/-9789244562635_rus.pdf? sequence $=1$ (in Russian)

44. Sydoruk N.L. (2010). Systema upravlinnia ekonomichnymy ryzykamy hospodarskoi diialnosti pidpryiemstva. [System of management of economic risks of enterprise economic activity]. Ekonomichni nauky. Ekonomika pidpryiemstvaEconomic sciences. Business Economics. Retrieved from: http://www.rusnauka.com/ 17_AND_2010/Economics/-69266.doc.htm. (in Ukrainian)

45. Sinki Dzh. (2007). Finansovyiy menedzhment v kommercheskom banke i $\mathrm{v}$ industrii finansovyih uslug. [Financial management in a commercial bank and in the financial services industry]. (p. 13). M.: Alpina Biznes Buks. Retrieved from: http://virtua.nsaem.ru:8001/mm/2008/000096859.pdf (in Russian) 


\section{Chapter «State administration»}

46. Slovnyk ukrainskoi movy. [Dictionary of the Ukrainian language]. Retrieved from: http://sum.in.ua/s/rysk (in Ukrainian)

47. Sutnist ryzykiv $u$ diialnosti pidpryiemstva. [The essence of the risks in the activities of the enterprise.]. Retrieved from: http://ukr.vipreshebnik.ru/uprrizik/3993-sutnist-rizikiv-u-diyalnosti-pidpriemstva.html (in Ukrainian)

48. Tertychka V. (2002). Derzhavna polityka: analiz ta zdiisnennia V Ukraini. [State Policy: Analysis and Implementation in Ukraine]. (p. 750). K.: Vydavnytstvo Solomii Pavlychko «Osnovy». Retrieved from: https://moodle.znu.edu.ua/pluginfile.php?file $=/ 180489 / \mathrm{mod}$ resource $/$ conten $\mathrm{t} / 1 / \% \mathrm{D} 0 \% \mathrm{~A} 2 \% \mathrm{D} 0 \% \mathrm{~B} 5 \% \mathrm{D} 1 \% 80 \% \mathrm{D} 1 \% 82 \% \mathrm{D} 0 \% \mathrm{~B} 8 \% \mathrm{D} 1 \% 87 \% \mathrm{D} 0 \% \mathrm{BA} \%$ D0\%B0\%20\%D0\%92.\%20\%D0\%94\%D0\%B5\%D1\%80\%D0\%B6\%D0\%B0

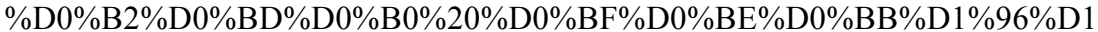
$\% 82 \% \mathrm{D} 0 \% \mathrm{~B} 8 \% \mathrm{D} 0 \% \mathrm{BA} \% \mathrm{D} 0 \% \mathrm{~B} 0 \% 20 \% \mathrm{D} 0 \% \mathrm{~B} 0 \% \mathrm{D} 0 \% \mathrm{BD} \% \mathrm{D} 0 \% \mathrm{~B} 0 \% \mathrm{D} 0 \% \mathrm{BB}$ $\% \mathrm{D} 1 \% 96 \% \mathrm{D} 0 \% \mathrm{~B} 7 \% 20 \% \mathrm{D} 1 \% 82 \% \mathrm{D} 0 \% \mathrm{~B} 0 \% 20 \% \mathrm{D} 0 \% \mathrm{~B} 7 \% \mathrm{D} 0 \% \mathrm{~B} 4 \% \mathrm{D} 1 \% 96 \%-$ D0\%B $\%$ D $1 \% 81 \%$ D0 $\%$ BD $\%$ D0\%B $\%$ D0\%BD $\%$ D0\%BD $\%$ D $1 \% 8$ F $\% 20$ $\%$ D0\%B2\% $20 \%$ D0\%A 3\%D0\%BA\%D $1 \% 80 \%$ D0 $\%$ B $0 \%$ D $1 \% 97 \%$ D $0 \%$ B D\%D1\%96.pdf (in Ukrainian)

49. Tepman L.N. (2002). Riski v ekonomike. Ucheb. posobie dlya vuzov. [Risks in the economy: Textbook]. (p. 380). M.: YuNITI-DANA. Retrieved from: https://studfiles.net/preview/1099586/ (in Russian)

50. Tsabiiev O.M. (2009). Ekolohichna bezpeka. Konspekt lektsii. [Ecological safe: Abstract lecture]. (p. 139). Odesa: Nauka i tekhnika. (in Ukrainian) 